\title{
Clusters of Moderate Size Earthquakes along Main Central Thrust (MCT) in Himalaya
}

\author{
Basab Mukhopadhyay \\ Geodata and Database Division, Geological Survey of India, Kolkata, India \\ E-mail: basabmukhopadhyay@yahoo.com \\ Received April 25, 2011; revised June 6, 2011; accepted July 21, 2011
}

\begin{abstract}
The Main Central Thrust (MCT) in Himalaya is seismically active in segments. In recent times, strain release within these active segments produce five spatial clusters (A to E; Figure 1). The seismicity within the cluster zones occurs in two depth bands; corresponding to the base of upper and lower crust. Depth sections across the clusters illustrate gently dipping subducted Indian Plate, overriding Tibetan Plate and compressed Sedimentary Wedge in between, with mid crustal ramping of MCT. Several presumptions / hypotheses have been put forward to decipher the causes of clustering along MCT. These are segmental activation of MCT, cross fault interactions, zones of arc parallel and arc perpendicular compressions, pore pressure perturbations, low heat flow zones etc. But these hypotheses need to be evaluated in the future after more ground level data are available. The maximum size of seismic threat that MCT can produce is inferred to be around Mw 7.0 in those clusters.
\end{abstract}

Keywords: MCT, Himalaya, Earthquake, Seismic Clusters, Seismic Potential

\section{Introduction}

The E-W bow like shape with trend reversal and higher elevations at terminal ends, Nanga Parbat (Western Syntaxis) in the West and Namcha Barwa (Eastern Syntaxis) in the East (Figure 1) characterise the physiography of the Himalaya. Himalaya came into existence due to collision of Indian shield with Eurasian/Tibetan Plate, compression and sequential thrusting along major faults such as Main Central Thrust (MCT), Main Boundary Thrust (MBT) and Main Frontal Thrust (MFT) [1,2]. MCT, a major shear zone separating the Higher Himalayan Crystallines from the Lesser Himalayan Series, is a major thrust fault that has contributed to the formation of the Himalaya [3]. MCT is thought to be an early Paleozoic Suture Zone [4-6]. It extends for nearly $2500 \mathrm{~km}$ along strike and has been the site of at least $120-140 \mathrm{~km}$ and perhaps more than $600 \mathrm{~km}$ of displacement [7-9] from its formational site. In recent times, due to locking of Himalayan thrust in the frontal part, the interactions between MFT, MBT and allied thrust planes have generated many great earthquakes (1905 Kangra, 1934 Bihar, 2005 Kashmir etc.) in the frontal belt of Himalaya. Though Lesser Himalayan earthquakes and related seismic hazards have been studied in details [10], the seis- mogenesis due to MCT and clustering of earthquakes related to this are somewhat neglected or oversimplified. At the same time, the seismic potentiality of the MCT to generate moderate size events (1980 Gangtok, 1991 Uttarkashi, 1999 Chamoli, 2009 Bomdila etc.) in the MCT proper and/or along its mid crustal ramp zone is also debated. Over and all, the assessment of earthquake hazard due to MCT is always been under-played. In this particular note, the author has tried to unearth causes of moderate size seismic clustering along different parts of $\mathrm{MCT}$, its seismotectonic behaviour, interaction between sub-surface structures, and also to judge its seismic hazard potentiality.

\section{Himalaya and Some Salient Features on MCT}

The pioneering research of Seeber, Armbruster and Quittmeyer [11], was the first to suggest a tectonic model of the Himalaya from seismic data analysis and suggested a gently dipping Indian slab, overriding Tethyan slab (Tibetan Plate) and a tapering Sedimentary Wedge (SW) (as shown in Figure 2(a)). The Sedimentary Wedge is decoupled from the Indian and Tethyan slabs at its boundary. Simultaneous activation of MCT and MBT is 


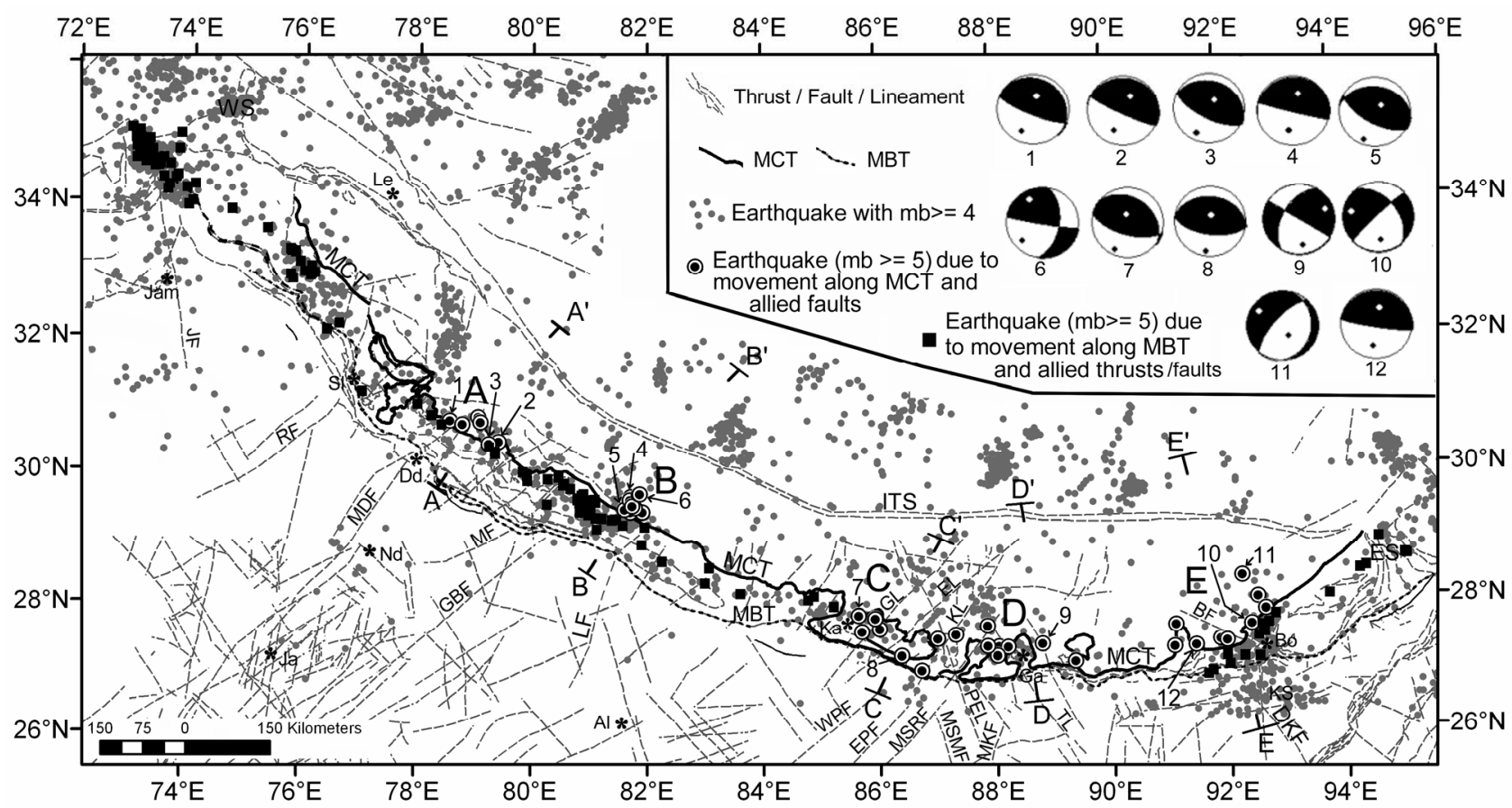

Figure 1. Seismo-tectonic map of Himalaya with earthquake $(\mathrm{mb} \geq 4)$, major thrusts, faults and lineaments. Earthquakes (mb $\geq 5$ ) generated by MBT (black square) and MCT (black circle with white outer rim) and its allied thrusts are shown. A- A' to E- E' is section lines. Note the CMT beachballs in the map with its number plotted. BF - Bomdila Fault, DKF - Dhansiri Kopili Fault, EL - Everest Lineament, EPF - East - Patna Fault, ES - Eastern Syntaxis, GBF - Great Boundary Fault, GL Gaurishankar Lineament, ITS - Indus - Tsangpo Suture, JF - Jhelum Fault, KL- Kanchenjungha Lineament, KS - Kalyani Shear, LF - Lucknow Fault, MBT - Main Boundary Thrust, MCT - Main Central Thrust, MDF - Mahendragarh Dehradun Fault, MF - Moradabad Fault, MKF - Malda - Kishanganj Fault, MSRF- Munger-Saharsa Ridge Fault, MSMF Munger-Saharsa Ridge Marginal Fault, PEL - Purnia - Everest Lineament, RF- Ropar Fault, SF - Sundernagar Fault, TL Tista Lineament, WPF - West Patna Fault, WS - Western Syntaxis, Al - Allahabad, Bo - Bomdila, Dd - Dehradun, Ga Gangtok, Ja - Jaipur, Jam - Jammu, K- Kathmandu, Nd - New Delhi, SI - Simla.

also proposed in this model. However, Ni and Barazangi [12] argued that MCT is dormant presently and MBT is active. In their model, the interface between the subducting slabs and sedimentary wedge is a 'plane of detachment'. The zone between 'plane of detachment' and junction between Sedimentary Wedge and Tibetan Plate roughly coincides with the high topographic gradient between Lesser and Higher Himalaya and characterised by steep dip, ramping of MCT and Himalayan crust at the northern edge of Indian Plate [7,13-15]. Further, the geometry of the Himalayan collision boundary is wedgeshaped; the base of this wedge is defined by a decollement, Main Himalayan Thrust (MHT), a major reflector that has been identified by seismic investigation [16]. The wedge defines crustal scale fault bend folds, formation of Lesser Himalayan Duplex that forms taper and controlled the foreland-ward propagation of the thrust sheets [17]. The metamorphic grade within the Lesser Himalaya increases towards the MCT with highest-grade rocks (kyanite and sillimanite gneisses) is found within the MCT shear zone. The MCT shear zone is characterized by a well-documented inverted metamorphism.
Arita [18] placed two thrusts (MCT-I and MCT-II) on each side of the MCT shear zone.

MCT, since its inception, has been activated, deactivated and again reactivated several times in the geological history and produces recurrent seismicity as it is accomplishing today. The movement along MCT and corresponding metamorphism, anatexis, followed by granite emplacement is found around 25 - 15 Ma with a peak at $21 \pm 0.5 \mathrm{Ma}$ [19]. The youngest deformation episode is marked around 3.1 Ma [20]. Recent SHRIMP monazite and zircon geochronology provides evidences of anatexis affecting the upper portion of the MCT shear zone occurred during Early Oligocene $(\sim 31 \mathrm{Ma})$ [21]. The samples from the base of Main Central Thrust yield $4.5 \pm 1.1 \mathrm{Ma}\left(T=540 \pm 25^{\circ} \mathrm{C}\right.$ and $P=700 \pm 180 \mathrm{MPa}$ from coexisting assemblage) and $4.3 \pm 0.1 \mathrm{Ma}$ (five grains) matrix monazite ages, suggesting Pliocene reactivation of the structure [22]. Cooling ages and geomorphic considerations have been taken to suggest that the MCT zone was activated in the early Miocene [23] and may have been reactivated as an out of sequence thrust in the Pliocene [24] and may even still be active [25]. Further, 

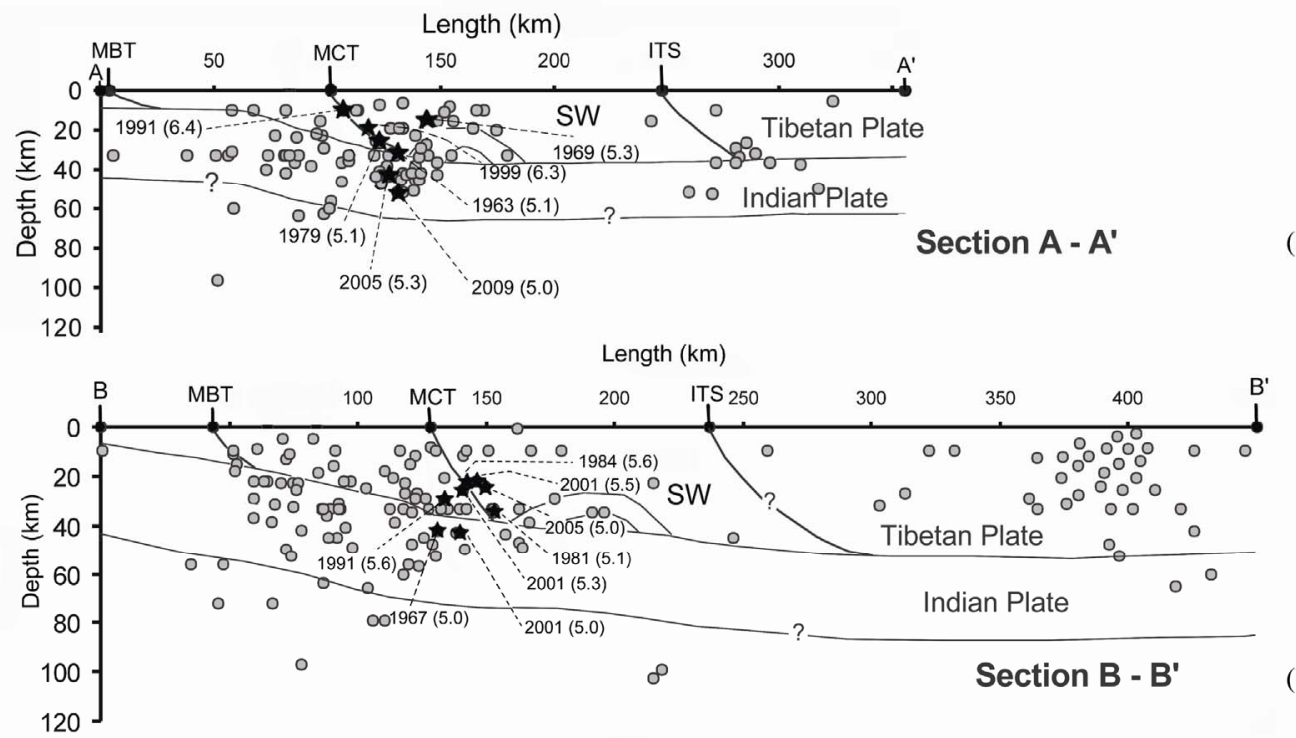

(b)
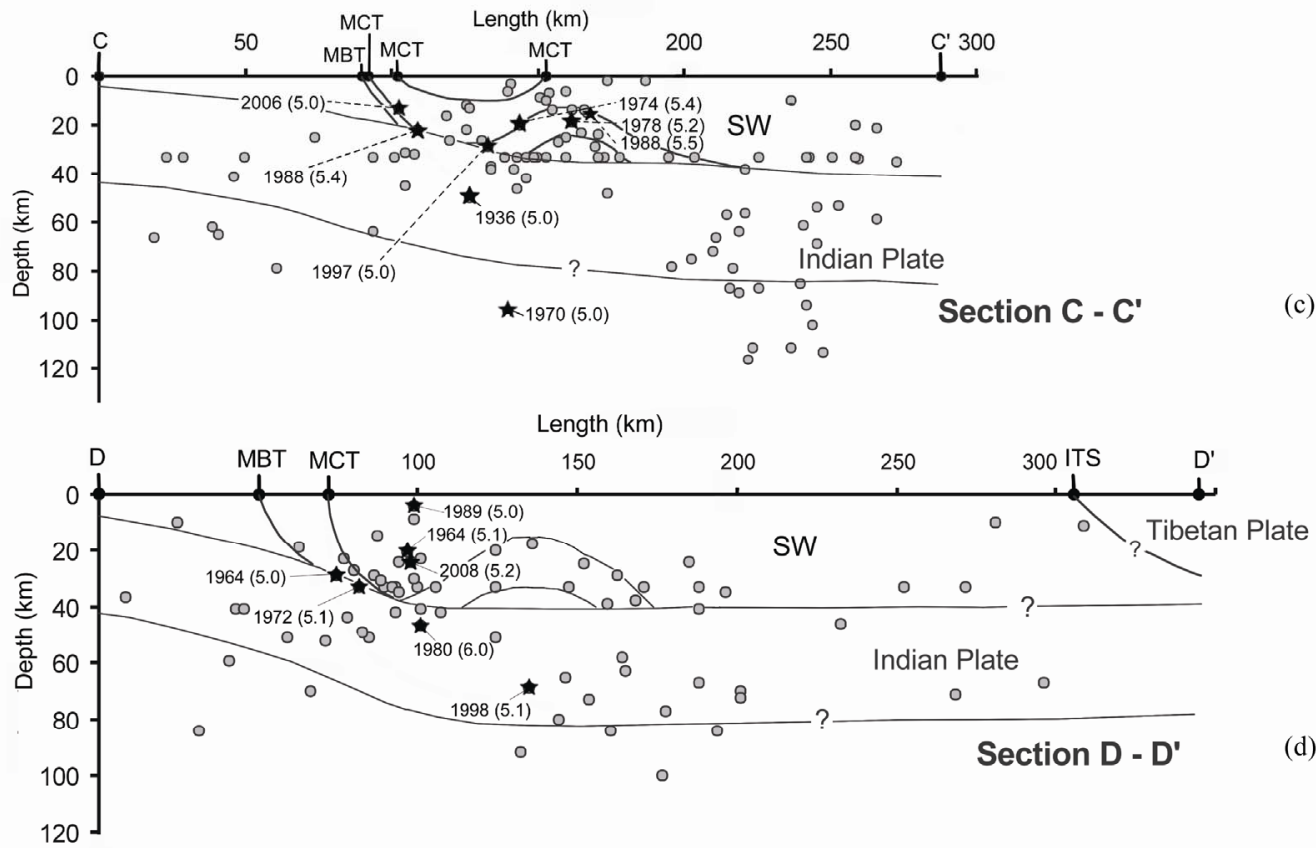

(d)

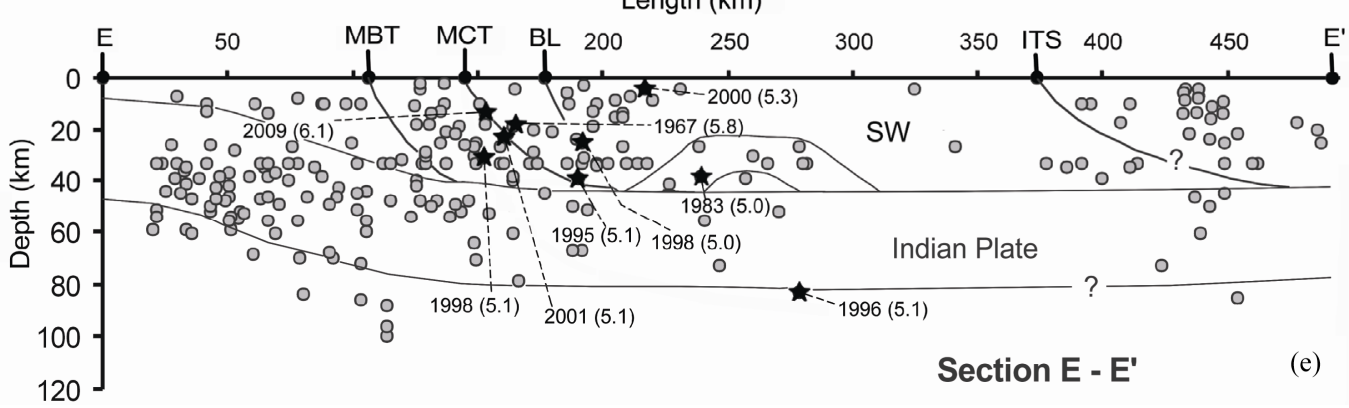

Figure 2. Schematic seismo-tectonic sections across Himalaya. Position of section lines (A-A' to E-E') is marked in Figure 1 and corresponding sections are numbered (a) to (e) respectively. Note the subducting Indian plate, overriding Tibetan plate and an ever-compressed Sedimentary Wedge (SW) in between. Also make a note of the mid-crustal ramp of MCT in all the sections. Earthquakes of table-1 are plotted with star symbol and annotated with year and magnitude (mb). In these depth sections, relocated seismic events using EHB technique (courtesy: Prof. E. R. Engdahl) are also used. 
knickpoints in the gradient of major rivers is southern part of Himalaya corresponds to the traces of MCT which in turn suggest that some segments of MCT may still be active [26]. Supporting evidences of neotectonic activities along MCT is obtained from topographic and geodetic data [27]. From the above discussion, it is apparent that parts of MCT are still active today as an out of sequence thrust and produce seismicity.

\section{Data}

Well-located earthquake data for the time period between 1905 and 2009 (source ISS/ISC/NEIC) with magnitude $(\mathrm{mb} \geq 4)$ has been used for this study. The earthquake epicentre plot on map (Figure 1) over a tectonic base map [after [28]] has brought out the earthquake distribution pattern in this terrain. The earthquakes (magnitude $\geq 5$ ) that have been generated by possible movements along MBT \& allied thrust planes (solid black boxes) are marked. Further, the events with magnitude $\geq 5$ that may have been spawned due to the movement along MCT and/or by sympathetic thrust planes are plotted with symbols (black circles with white outer rim). The CMT solutions of these events are extracted from HRVD web site (Table 1) and plotted with corresponding numbers and beach ball circles. The earthquake events of Table 1 are found to cluster in certain geographical locales from west to east (A to E). Five depth sections (A-A' to E-E'), position marked in Figure 1, were drawn through these clusters (Figures 2(a) - (e)) to unravel the crustal configurations, relation of earthquakes with seismogenic surfaces and to access the overall tectonic scenario. In these depth sections, relocated seismic events using EHB technique (Dr. E. R. Engdahl, personal communication) are also used.

\section{Seismotectonics and Depth Sections across MCT}

The beach-ball diagrams of 12 earthquakes of Table 1 are plotted in Figure 1. Except for numbers 6, 9 and 10, by and large all the solutions show predominant thrust movement along WNW-ESE / NW-SE trending thrust planes dipping low angle towards north. The solutions 6 , 9 and 10 belong to clusters $\mathrm{B}, \mathrm{D}$ and $\mathrm{E}$ respectively (Table 1) show strike slip movements along N-S/NW-SE trending fault planes dipping moderately towards east. Beach balls (Figure 1) of larger earthquakes like 1991 Uttarkashi (plot no. 1), 1999 Chamoli earthquake (plot no. 2) and 2009 Bomdila earthquake (plot no. 12) show consistent thrust fault plane solutions along NW-SE trending thrust planes dipping low angle $6^{\circ}-14^{\circ}$ towards northeast. It indicates the strike and dip of the seismically active thrusts in Western and Eastern Himalaya.

In depth sections (Figure 2) the general seismicity $(\mathrm{mb} \geq 4)$ as filled circles; projections of tectonic planes, Indian \& Tibetan Plates and intervening Sedimentary Wedge, and Table 1 earthquakes with star symbols are plotted. Gently dipping Indian plate and its existence below Tibet is inferred from the seismic data distribution. Further, mid crustal ramping of MCT as shown in the INDEPTH profile [15] is also inferred in all these sections from the distributions of seismicity and topographic relief data. From the sections, it is inferred that recent seismicity in Himalaya is restricted in two distinct places: one along the zone between MFT/MBT and MCT, and another beyond Indus Tsangpo Suture (ITS) in Tibet.

The section along cluster 'A' (section A-A' of Figure 2(a)) shows cluster of seismicity in the interface between MCT and upper part of down going Indian Plate. This section contains two important and well-studied earthquakes of Himalaya, Uttarkashi earthquake of 1991 and Chamoli earthquake of 1999. The Uttarkashi earthquake of 1991 was associated with the Main Central Thrust zone of Himalaya (just south of the Vaikrita thrust, also interpreted as MCT 1) occurred at a depth of $15 \pm 1.5 \mathrm{~km}$ (constrained by depth phase pP-P, ISC) [29]. Whereas, the 1999 Chamoli mainshock $\left(30.512 \pm 0.04^{\circ} \mathrm{N}, 79.403\right.$ $\pm 0.024^{\circ} \mathrm{E}$ ) occurred on a $9^{\circ}$ north dipping thrust at a depth of $15 \mathrm{~km}$ beneath a region about $25 \mathrm{~km}$ NNE of Chamoli in Himachal Pradesh. A total of 204 aftershocks of magnitude varying from 1.4 to 4.8 were recorded by NGRI during 4 April 1999 through 20 May 1999. The estimated hypocentral parameters for these well-located aftershocks delineate three distinct seismic trends corresponding to: 1) a detachment surface dipping at $15^{\circ}$ to NNE at depths of $10-16 \mathrm{~km}$; 2) Munsiari (MCT 2) thrust dipping at $45^{\circ}$ to $\mathrm{NE}$ at depths $2-16 \mathrm{~km}$; and 3) $\mathrm{NE}$ trending transverse fault dipping at $45^{\circ}$ to $\mathrm{SE}$ extending from a depth of 4 to $10 \mathrm{~km}[30,31]$. They also revealed that the mainshock occurred near a junction between the detachment surface and MCT 2 at a depth of $15 \mathrm{~km}$. In the contrary, the occurrence of Chamoli earthquake from a seismogenic fault, south of the Main Central Thrust (MCT) by thrust faulting as well as by strike-slip faulting was also advocated [32]. From the above discussion, it is apparent that the 1991 Uttarkashi and 1999 Chamoli earthquakes ( $\mathrm{Mw} 6.8$ and 6.6 respectively, Table 1) have been generated due to thrust movement along MCT and/or crustal ramp zone of MCT. Thus the MCT proper, its sympathetic faults and crustal ramps below the higher Himalaya are seismogenic in this sector.

Similar scenario exists in sections B-B' and C-C' (Figures 2(b) and (c)) drawn through clusters B and C, where the thrust movement along MCT or in the crustal 
Table 1. Earthquakes $(\mathrm{mb} \geq 5)$ occurred due to movement of MCT and related thrusts are tabulated. The CMT solutions (Source www.seismology.harvard.edu) for 12 earthquakes due to MCT are tabulated. The solution parameters are discussed in text. The value of column marked as (No) is plotted on the map (Figure 1). YR - Year, MO - Month, DT - Day. HR - Hour, MN - Minute, SEC - Second, T - Tension, N - Neutral, P - Compression, FP - Fault Plane.

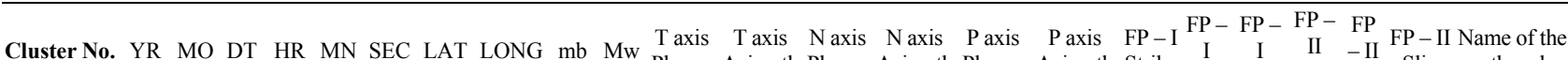
Plunge Azimuth Plunge Azimuth Plunge Azimuth Strike I $\begin{aligned} & \text { I II } \\ & \text { Dip }\end{aligned}$ Slip Strik Dip Slip earthquake

\begin{tabular}{|c|c|c|c|c|c|c|c|c|c|c|c|c|c|c|c|c|c|c|c|c|c|c|c|c|}
\hline $\mathbf{A}$ & & 1963 & 11 & 27 & 21 & 10 & 40 & 30.8 & 79.10 & 5.1 & & & & & & & & & & & & & & \\
\hline $\mathbf{A}$ & & 1969 & 6 & 22 & 1 & 33 & 23 & 30.5 & 79.40 & 5.3 & & & & & & & & & & & & & & \\
\hline $\mathbf{A}$ & & 1979 & 12 & 28 & 1 & 59 & 18 & 30.8 & 78.57 & 5 & & & & & & & & & & & & & & \\
\hline $\mathbf{A}$ & 1 & 1991 & 10 & 19 & 21 & 23 & 15 & 30.8 & 78.79 & 6.4 & 6.8 & 57 & 14 & 6 & 113 & 32 & 207 & 317 & 14 & 115 & 112 & 78 & 84 & $\begin{array}{l}\text { Uttarkashi } \\
\text { Earthquake }\end{array}$ \\
\hline $\mathbf{A}$ & 2 & 1999 & 3 & 28 & 19 & 5 & 12 & 30.5 & 79.40 & 6.3 & 6.6 & 52 & 27 & 2 & 295 & 38 & 203 & 280 & 7 & 75 & 115 & 83 & 92 & $\begin{array}{l}\text { Chamoli } \\
\text { Earthquake }\end{array}$ \\
\hline $\mathbf{A}$ & 3 & 2005 & 12 & 14 & 7 & 9 & 54 & 30.5 & 79.25 & 5.3 & 5.1 & 68 & 30 & 1 & 296 & 22 & 206 & 293 & 23 & 86 & 117 & 67 & 92 & \\
\hline $\mathbf{A}$ & & 2009 & 9 & 21 & 9 & 43 & 51 & 30.9 & 79.06 & 5 & & & & & & & & & & & & & & \\
\hline B & & 1967 & 12 & 18 & 10 & 51 & 36 & 29.5 & 81.71 & 5 & & & & & & & & & & & & & & \\
\hline B & & 1981 & 5 & 15 & 17 & 22 & 43 & 29.5 & 81.92 & 5.1 & & & & & & & & & & & & & & \\
\hline B & & 1984 & 5 & 18 & 4 & 28 & 52 & 29.5 & 81.79 & 5.6 & & & & & & & & & & & & & & \\
\hline B & & 1991 & 12 & 9 & 1 & 2 & 42 & 29.5 & 81.61 & 5.6 & & & & & & & & & & & & & & \\
\hline B & 4 & 2001 & 11 & 27 & 7 & 31 & 52 & 29.7 & 81.72 & 5.5 & 5.5 & 48 & 16 & 2 & 284 & 42 & 192 & 257 & 4 & 63 & 104 & 87 & 92 & \\
\hline B & 5 & 2001 & 11 & 27 & 8 & 53 & 54 & 29.6 & 81.7 & 5.3 & 5.4 & 70 & 46 & 8 & 295 & 18 & 202 & 280 & 28 & 73 & 119 & 64 & 99 & \\
\hline B & & 2001 & 11 & 27 & 17 & 56 & 57 & 29.6 & 81.74 & 5 & & & & & & & & & & & & & & \\
\hline B & 6 & 2005 & 10 & 31 & 5 & 51 & 16 & 29.7 & 81.86 & 5 & 4.8 & 28 & 331 & 51 & 103 & 24 & 227 & 8 & 52 & 176 & 100 & 87 & 39 & \\
\hline B & & 2005 & 11 & 6 & 1 & 36 & 57 & 29.7 & 81.87 & 5 & & & & & & & & & & & & & & \\
\hline C & & 1936 & 2 & 11 & 4 & 48 & 0 & 27.5 & 87 & 5.5 & & & & & & & & & & & & & & \\
\hline C & & 1970 & 2 & 26 & 19 & 30 & 14 & 27.6 & 85.7 & 5 & & & & & & & & & & & & & & \\
\hline C & & 1974 & 3 & 24 & 14 & 16 & 1 & 27.7 & 86 & 5.4 & & & & & & & & & & & & & & \\
\hline C & & 1978 & 10 & 4 & 13 & 53 & 51 & 27.8 & 85.93 & 5.2 & & & & & & & & & & & & & & \\
\hline C & & 1988 & 4 & 20 & 6 & 40 & 26 & 27 & 86.72 & 5.4 & & & & & & & & & & & & & & \\
\hline C & 7 & 1988 & 10 & 29 & 9 & 10 & 53 & 27.9 & 85.64 & 5.5 & 5.2 & 71 & 352 & 10 & 112 & 16 & 205 & 309 & 30 & 109 & 106 & 62 & 79 & \\
\hline C & 8 & 2006 & 2 & 3 & 1 & 57 & 47 & 27.3 & 86.38 & 5 & 4.8 & 75 & 6 & 0 & 98 & 15 & 188 & 279 & 30 & 91 & 98 & 60 & 90 & \\
\hline D & & 1964 & 8 & 30 & 2 & 35 & 7 & 27.4 & 88.21 & 5.1 & & & & & & & & & & & & & & \\
\hline D & & 1964 & 3 & 27 & 23 & 3 & 41 & 27.1 & 89.36 & 5 & & & & & & & & & & & & & & \\
\hline D & & 1972 & 8 & 21 & 18 & 55 & 7 & 27.2 & 88.02 & 5.1 & & & & & & & & & & & & & & \\
\hline D & 9 & 1980 & 11 & 19 & 19 & 0 & 45 & 27.4 & 88.80 & 6 & 6.3 & 25 & 68 & 51 & 302 & 28 & 172 & 209 & 51 & -2 & 301 & 89 & -141 & $\begin{array}{l}\text { Gangtok } \\
\text { Earthquake }\end{array}$ \\
\hline D & & 1989 & 5 & 22 & 19 & 24 & 31 & 27.4 & 87.86 & 5 & & & & & & & & & & & & & & \\
\hline D & & 1998 & 11 & 26 & 10 & 24 & 23 & 27.7 & 87.86 & 5.1 & & & & & & & & & & & & & & \\
\hline D & & 2008 & 12 & 2 & 5 & 11 & 42 & 27.4 & 88.05 & 5.2 & & & & & & & & & & & & & & \\
\hline $\mathbf{E}$ & & 1967 & 9 & 15 & 10 & 32 & 44 & 27.4 & 91.86 & 5.8 & & & & & & & & & & & & & & \\
\hline $\mathbf{E}$ & & 1983 & 10 & 2 & 21 & 3 & 24 & 28.1 & 92.52 & 5 & & & & & & & & & & & & & & \\
\hline $\mathbf{E}$ & 10 & 1995 & 2 & 17 & 2 & 44 & 25 & 27.6 & 92.40 & 5.1 & 5.5 & 25 & 282 & 46 & 40 & 34 & 174 & 322 & 46 & -172 & 226 & 84 & -44 & \\
\hline $\mathbf{E}$ & 11 & 1996 & 6 & 9 & 23 & 25 & 16 & 28.4 & 92.26 & 5.1 & 5.2 & 24 & 303 & 10 & 37 & 64 & 149 & 12 & 23 & -117 & 221 & 69 & -79 & \\
\hline $\mathbf{E}$ & & 1998 & 7 & 8 & 3 & 44 & 59 & 27.3 & 91.07 & 5.1 & & & & & & & & & & & & & & \\
\hline $\mathbf{E}$ & & 1998 & 8 & 18 & 4 & 10 & 23 & 27.7 & 91.10 & 5 & & & & & & & & & & & & & & \\
\hline $\mathbf{E}$ & & 2000 & 1 & 25 & 16 & 43 & 19 & 27.9 & 92.65 & 5.3 & & & & & & & & & & & & & & \\
\hline $\mathbf{E}$ & & 2001 & 11 & 6 & 14 & 9 & 24 & 27.4 & 91.97 & 5.1 & & & & & & & & & & & & & & \\
\hline $\mathbf{E}$ & 12 & 2009 & 9 & 21 & 8 & 53 & 6 & 27.3 & 91.44 & 6.1 & 6.1 & 51 & 10 & 1 & 279 & 39 & 189 & 274 & 6 & 85 & 99 & 84 & 91 & $\begin{array}{l}\text { Bomdila } \\
\text { Earthquake }\end{array}$ \\
\hline
\end{tabular}


ramp zone of MCT again defines seismicity. The 1980 Gangtok earthquake (Mw 6.3, Table 1) generated due to interaction of MCT and the upper part of Indian Plate boundary (section D - D', Figure 2(d)) by a strike slip motion. Further, the 2009 Bomdila earthquake (Mw 6.1. Table 1) has also been generated due to thrust movement along MCT (section E-E', Figure 2(e)).

\section{Some Assumption for Clustering of Moderate Size Earthquakes along MCT}

It is found that moderate size earthquake events (magnitude $\geq 5$ ) clusters in only five places (A to E, Figure 1) due to probable movement of MCT. Inter-cluster zones, which are comparatively large in area, are almost devoid of MCT induced seismicity. Some propositions/explanations are summarised below to explain such phenomenon.

1) It is known that active movements along fault plane occur in segments. The cluster zones are those segments of MCT that are presently active.

2) The cluster zones are the zones of strain accumulation. It is also found elsewhere that domains of intersecting major discontinuity surfaces are favourable locales for stress build up and can be considered as sites of seismic potentiality [33]. In cluster zone, strain is accumulated due to cross fault interactions between transgressing northerly trending deep seated faults from Peninsular Shield with E-W trending shallower Himalayan thrusts (see Figure 1). Such interaction is inferred in cluster A [where NNE-SSW trending Mahendragarh Dehradun Fault (MDF) is in interaction with WNW-ESE trending MBT \& MCT]; in cluster ' $\mathrm{B}$ ' [where NE-SW trending Great Boundary Fault (GBF), N-S trending Lucknow Fault (LF) is in interaction with WNW-ESE trending MBT \& MCT]; in cluster ' $\mathrm{C}$ ' [NE-SW trending West Patna Fault (WPF), East - Patna Fault (EPF), Munger-Saharsa Ridge Fault (MSRF) with E-W trending MBT \& MCT]; in cluster ' $D$ ' [NNW-SSE trending Purnia - Everest Lineament (PEL), Malda - Kishanganj Fault (MKF), Tista Lineament (TL) with E-W trending MBT \& MCT] and finally in cluster ' $\mathrm{E}$ ' [NW-SE trending Dhansiri - Kopili Fault (DKF), Bomdila Fault (BF) with ENE-WSW trending MBT \& MCT]. Such scenario is either absent or not active in inter-cluster zones.

3) In these cluster zones, the seismic slips release the accumulated strain whereas in the inter-cluster zones, probable aseismic creep (?) release the strain gradually.

4) In cluster zones, both Indian Plate and overriding Sedimentary Wedge have participated equally in releasing the seismogenic strain by earthquakes (Thick Skinned Tectonics). This is probably absent in the intercluster zones.
5) Following the model of Seeber and Pecher [34] on Himalaya, the Himalayan arc to maintain its arcuate geometry need arc parallel extensions in several places, in addition to the layer perpendicular compressional stress due to plate convergence. The zones between two extension zones, thus, experience both layer parallel and layer perpendicular compressions. The cluster zones define those areas where crust experiences both arc parallel and arc perpendicular compressions. This is primarily manifested by thrust type of earthquakes with subordinate strike slip motion. The CMT solution also conforms this hypothesis by showing: a) two perpen- dicular sets of causative fault planes, one along WNW- ESE/NW-SE trending thrust planes dipping low angle towards north and other N-S/NW-SE trending fault planes dipping moderately towards east, and $\mathrm{b}$ ) change in the orientation of compression (P) axis from NNE-SSW/ NE-SW to NW-SE plunging low to moderately (Table 1).

6) Due to cross-faulting and repeated rupturing, the cluster zones are places of newly developed micro and major cracks within a highly fractured crust. These microcracks accumulate strains at its tips [as indicated by 'Griffith's crack theory'] and encourage repeated failure over a threshold stress limit. Further, the percolations of rainwater within these cracks induce pore-pressure perturbation and thus enhance the chance of failure in lower stress followed by generation of moderate size earthquakes at crustal level.

7) The cluster zones are the places of probable low heat flow due to depression in Moho. Depression in Moho suggests more seismogenic volume. The experiments to determine Moho in several parts of Himalaya reveal variable depths. In western Himalaya, the Moho deepens northward across the foredeep and is at $50 \mathrm{~km}$ depths beneath the foothills of the Himalaya and $60-65$ $\mathrm{km}$ depth beneath the highest part of the Himalaya [35]. In Nepal Himalaya, the subsurface images from HIMNT teleseismic receiver functions and local earthquake tomography show an increase in Moho depth from $\sim 45 \mathrm{~km}$ beneath Nepal to $\sim 75 \mathrm{~km}$ beneath Tibet [36]. Bhattacharya et al. [37] inferred a Moho depth of $\sim(45-47) \mathrm{km}$ below lesser Himalayan part of Western Arunachal Himalaya. It is also evident from seismic depth sections (Figure 2) that earthquakes generated due to MCT and sympathetic thrust occurs in two depth bands, $15-25 \mathrm{~km}$ corresponding to the base of upper Crust and $35-45 \mathrm{~km}$ corresponding to the base of lower Crust. Thus, it can be inferred that in the zone of clusters, the Moho depth may be higher $(\sim 50 \mathrm{~km})$ with lower heat flow, more brittle deformation, in comparison to non-cluster zones.

\section{Conclusions}

The results in this study suggest that MCT is not dormant 
but active in segments. The active segments produce seismic clusters (A to $E$ ) of moderate size earthquake events in recent time. The magnitude of the events generated so far is restricted below Mw 7.0 (Table 1). Thus the seismic potentiality of MCT within these clusters can be inferred as Mw 7.0. This value can probably be used for engineering design purposes. But this inference needs to be exercise with caution as this analysis has only considered seismic record for the last 105 years. The earthquake data prior to 1905 are mainly historical and have large locational errors and thus are not used in this analysis.

The depth sections show gently dipping subducted Indian plate, overriding Tibetan Plate and compressed Sedimentary Wedge, steep dip and mid crustal ramping of MCT. The seismicity along the clusters are also found to be restricted to two depth bands, $15-25 \mathrm{~km}$ corresponding to the base of upper Crust and $35-45 \mathrm{~km}$ related to the base of lower Crust, with an inferred Moho depth of nearly $50 \mathrm{~km}$. Several inferences has been drawn for the cause of clustering of earthquakes along MCT; like segmental activation of MCT, cross fault interactions, zones of arc parallel and arc perpendicular compressions, pore pressure perturbations, low heat flow etc. But these hypotheses need to be backed by experimental data. These inferences hold good for clustering of earthquakes in the Himalaya, especially in the lesser Himalaya where a characteristic earthquake model is apparent [10].

\section{References}

[1] K. S. Valdiya, "Himalayan Transverse Faults and Their Parallelism with subsurface Structures of North Indian Plains," Tectonophysics, Vol. 32, No. 3-4, 1976, pp. 352-386. doi:10.1016/0040-1951(76)90069-X

[2] P. Le Fort, "Metamorphism and Magmatism during the Himalayan Collision," In: M. P. Coward, A. C. Ries, Eds., Collision Tectonics, Geol. Soc. Spec. Publ., Vol. 19, 1986, pp. 159-172.

[3] L. Bollinger, P. Henry and J.P. Avouac, "Mountain Building in the Nepal Himalaya: Thermal and Kinematic Model," Earth and Planetary Science Letters, Vol. 244, No. 1-2, 2006, pp. 58-71. doi:10.1016/j.epsl.2006.01.045

[4] R. M. Manickavasagam, A. K. Jain, S. Singh, A. Asokan, A. Macfarlane, R. Sorkhabi and J. Quade, "Metamorphic Evolution of the Northwest Himalaya, India; PressureTemperature Data, Inverted Metamorphism, and Exhumation in the Kashmir, Himachal, and Garhwal Himalayas Himalaya and Tibet; Mountain Roots to Mountain Tops," Special Paper-Geological Society of America, Vol. 328, 1999, pp. 179-198.

[5] P. G. Decelles, G. E. Gehrels, J. Quade, B. Lareau and M. Spurlin, "Tectonic Implications of U-Pb Zircon Ages of the Himalayan Orogenic Belt in Nepal", Science, Vol. 288, No. 5465, 2000, pp. 497-499.

\section{doi:10.1126/science.288.5465.497}

[6] D. Marquer, H. S. Chawla and N. Challandes, "Pre-Alpine High Grade Metamorphism in High Himalaya Crystalline Sequences: Evidences from Lower Palaeozoic Kinnar Kailas Granite and Surrounding Rocks in the Sutlej Valley (Himachal Pradesch, India)," Eclogae Geologicae Helvetiae, Vol. 93, 2000, pp. 207-220.

[7] D. Schelling and K. Arita, "Thrust Tectonics, Crustal Shortening, and the Structure of the Far-Eastern Nepal Himalaya", Tectonics, Vol. 10, No. 5, 1991, pp. 851-862. doi:10.1029/91TC01011

[8] P. Srivastava and G. Mitra, "Thrust Geometries and Deep Structure of the Outer and Lesser Himalaya, Kumaon and Garhwal (India): Implications for Evolution of the Himalayan Fold and Thrust Belt," Tectonics, Vol. 13, No. 1, 1994, pp. 89-109. doi:10.1029/93TC01130

[9] O. N. Pearson and P. G. Decelles, "Structural Geology and regional Tectonic Significance of the Ramgarh Thrust, Himalayan Fold-Thrust Belt of Nepal", Tectonics, Vol. 24, 2005, p. TC4008. doi:10.1029/2003TC001617

[10] B. Mukhopadhyay, A. Acharyya and S. Dasgupta, "Potential Source Zones for Himalayan Earthquake: Constraints from Spatial-Temporal Clusters", Natural Hazards, Vol 57, No. 2, 2011, pp. 369-383. doi:10.1007/s11069-010-9618-2

[11] L. Seeber, J. G. Armbruster and R. Quittmeyer, "Seismicity and Continental Subduction in the Himalayan Arc", In: H. K. Gupta and F. M. Delany, Eds., Zagros, Hindu Kush, Himalaya Geodynamic Evolution, American Geographical Union, Washington, DC-Geodynamics Series, Vol. 4, 1981, pp. 215-242.

[12] J. F. Ni and M. Barazangi, "Seismotectonics of the Himalayan Collision Zone: Geometry of the Underthrusting Indian Plate beneath the Himalaya", Journal of Geophysical Research, Vol. 89, No. B2, 1984, pp. 1147-1163. doi:10.1029/JB089iB02p01147

[13] H. Lyon-Caen and P. Molnar, "Gravity Anomalies and the Structure of Western Tibet and Southern Tarim Basin," Geophysics Research Letter, Vol. 11, No. 12, 1983, pp. 1251-1254. doi:10.1029/GL011i012p01251

[14] J. Lavé and J.P. Avouac, “Active Folding of Fluvial Terraces across the Siwalik Hills (Himalaya of Central Nepal)", Journal of Geophysical Research, Vol. 105, No. B3, 2000, pp. 5735-5770. doi:10.1029/1999JB900292

[15] R. Cattin and J.P. Avouac, "Modeling Mountain Building and the Seismic Cycle in the Himalaya of Nepal", Journal of Geophysical Research, Vol. 105, No. B6, 2000, pp. 13389-13407. doi:10.1029/2000JB900032

[16] W. Zhao, K. D. Nelson, et al., "Deep seismic reflection evidence for continental underthrusting beneath southern Tibet", Nature, Vol. 366, 1993, pp. 557-559. doi: $10.1038 / 366557 \mathrm{a} 0$

[17] M. Mukul, "Himalayan Deformation: Insights from Darjiling-Sikkim-Tibet (DaSiT) Wedge", Journal of Asian Earth Sciences, Vol. 39, No. 6, 2010, pp. 645-657. doi:10.1016/j.jseaes.2010.04.029

[18] K. Arita, "Origin of the inverted metamorphism of the Lower Himalaya, Central Nepal", Tectonophysics, Vol. 
95, No. 1-2, 1983, pp. 43-60. doi:10.1016/0040-1951(83)90258-5

[19] S. M. Naqvi, "Geology and Evolution of the Indian Plate: from Hadean to Holocene", Capital Publishing Company, New Delhi, 2005, p. 450.

[20] P. Copeland, T. M. Harrison, K. V. Hodges, P. Maruejol, P. Lefort and A. Pecher, "An Early Pliocene Thermal Disturbance of Main Central Thrust, Central Nepal: Implication for Himalayan Tectonics," Journal of Geophysical Research, Vol. 96, No. B5, 1991, pp. 8475-8500. doi:10.1029/91JB00178

[21] C. Groppo, D. Rubatto, F. Rolfo and B. Lombardo, "Early Oligocene Partial Melting in the Main Central Thrust Zone (Arun Valley, Eastern Nepal Himalaya)," Lithos, Vol. 118, No. 3-4, 2010, pp. 287-301. doi:10.1016/j.lithos.2010.05.003

[22] E. J. Catlos, C. S. Dubey, R. A. Marston and M. T. Harrison, "Geochronologic Constraints across the Main Central Thrust Shear Zone, Bhagirathi River (NW India): Implications for Himalayan Tectonics," GSA Special Papers, Vol. 419, No. 4, 2007, pp. 135-151.

[23] M. S. Hubbard and T. M. Harrison, "40Ar/39Ar Age Con- Straints on Deformation and Metamorphism in the Main Central Thrust Zone and Tibetan Slab, Eastern Nepal Himalaya", Tectonics, Vol. 8, No. 4, 1989, pp. 865-880. doi:10.1029/TC008i004p00865

[24] T.M. Harrison, F.J. Ryerson, P. Le Fort, A. Yin, O.M. Lovera, and E.J. Catlos, "A Late Miocene-Pliocene Origin for the Central Himalayan Inverted Metamorphism," Earth Planet Science Letter, Vol. 146, No. 1-2, 1997, pp. E1-E8. doi:10.1016/S0012-821X(96)00215-4

[25] K. V. Hodges, C. Wobus, K. Ruhl, T. Schildgen and K. Whipple, "Quaternary Deformation, River Steepening, and Heavy Precipitation at the Front of the Higher Himalayan Ranges," Earth Planet Science Letter, Vol. 220, No. 3-4, 2004, pp. 379-389. doi:10.1016/S0012-821X(04)00063-9

[26] K. S. Valdiya, "Dynamic Himalaya," JNCASR, University Press (India) Limited, 2001, p. 178.

[27] R. Bilham, K. Larson, J. Freymuller et al., "GPS measurements of the present day convergence across the Nepal Himalaya," Nature, Vol. 386, 1997, pp. 61-63. doi: $10.1038 / 386061 \mathrm{a} 0$

[28] S. Dasgupta, P. Pande, D. Ganguly, Z. Iqbal, K. Sanyal, N. V. Venkatraman, S. Dasgupta, B. Sural, L. Harendranath, S. Mazumdar, S. Sanyal, A. Roy, L. K. Das, P. S. Misra and H. Gupta, "Seismotectonic Atlas of India and
Its Environs," Geological Survey of India, Kolkata, 2000, p. 86.

[29] F. Cotton, M. Campillo, A. Deschamps and B. K. Rastogi, "Rupture History and Seismotectonics of the 1991 Uttarkashi, Himalaya Earthquake," Tectonophysics, Vol. 258, No. 1-4, 1996, pp. 35-51. doi:10.1016/0040-1951(95)00154-9

[30] P. Mandal, B. K. Rastogi and H. K. Gupta, "Recent Indian earthquakes," Current Science, Vol. 79, No. 9, 2000, pp. 1334-1346.

[31] P. Mandal, S. Padhy, B. K. Rastogi, H. V. S. Satyanarayana, M. Kousalya, R. Vijayraghavan and A. Srinivasan, "Aftershock Activity and Frequency-Dependent Low Coda Qc in the Epicentral Region of the 1999 Chamoli Earthquake of Mw 6.4," Pure and Applied Geophysics, Vol. 158, No. 9-10, 2001, pp. 1719-1735. doi:10.1007/PL00001241

[32] J. R. Kayal, S. Ram, O. P. Singh, P. K. Chakraborty and G. Karunakar, "Aftershocks of the March 1999 Chamoli Earthquake and Seismotectonic Structure of the Garhwal Himalaya," Bulletin of the Seismological Society of America, Vol. 93, No. 1, 2003, pp. 109-117. doi:10.1785/0119990139

[33] D. J. Andrew, "Mechanics of Fault Junction," Journal of Geophysical Research, Vol. 94, No. B7, 1989, pp. 9389-9397. doi:10.1029/JB094iB07p09389

[34] L. Seeber and A. Pecher, "Strain Partitioning along the Himalayan Arc and Nanga Parbat Antiform," Geology, Vol. 26, No. 9, 1998, pp. 791-794. doi:10.1130/0091-7613(1998)026<0791:SPATHA $>2.3 . C$ $\underline{\mathrm{O} ; 2}$

[35] S. S. Rai, K. Priestley, V. K. Gaur, S. Mitra, M. P. Singh, and M. Searle, "Configuration of the Indian Moho beneath the NW Himalaya and Ladakh," Geophysical Research Letters, Vol. 33, 2006, p. 15308. doi:10.1029/2006GL026076

[36] A. F. Sheehan, T. Torre, G. Monsalve, V. SchultePelkum, R. Bilham, F. Blume, R. Bendick, F. Wu, M. R. Pandey, S. Sapkota and S. Rajaure, "Earthquakes and Crustal Structure of the Himalaya from the Himalayan Nepal Tibet Seismic Experiment (HIMNT)," Journal of the Nepal Geological Society, Vol. 38, 2008, pp. 1-8.

[37] P. M. Bhattacharya, S. Mukhopadhyay, R. K. Majumber and J. R. Kayal, "3-D Seismic Structure of Northeast India Region and Its Implication for Local and Regional Tectonics," Journal of Asian Earth Sciences, Vol. 33, No. 1-2, 2008, pp. 25-41. doi:10.1016/j.jseaes.2007.10.020 